\title{
Challenges and Prospects of Indigenous Shipowners' Participation in Oil Shipment In Nigeria
}

\author{
${ }^{1,2}$ Lawani, A. O* $\quad{ }^{1}$ E.N Amasike \\ 1.Federal University of Technology, Owerri, Imo state, Nigeria \\ 2.Federal College of Education, PMB 2096, Abeokuta, Nigeria
}

\begin{abstract}
If Nigeria's economy is essentially import based, then the issue and fact that her infrastructure for industrial development and export are grossly underdeveloped, when the nation is having abundant national mineral resources to improve on her foreign earning, being a maritime and oil producing nation, Nigeria is not gaining enough from this natural resources due to the poor position of policy guiding the shipping trade and oil business. In this research work emphasis was laid on indigenous shipping operations in the areas of cargo oil shipment (importation and exporting) with the necessary policy guiding the operation in the business i.e. the National Shipping Policy Act of April, 1987 and the United Nation Conference on Trade and Development (UNTAD) code of conduct on conference lines and the role of Nigerian National Petroleum Corporation (NNPC) in area of oil shipment as defined by the NNPC policy on oil transportation by sea. Emphasis on the demerits of foreign shipping lines, continued domination of the shipping trade particularly in area of oil cargo; the challenges, prospect and the need of indigenous participation in oil shipment business, that Nigeria can use at the benefit of balance of payment was researched. While, the foreign shipping lines and operators continue to dominate the oil shipment trade in Nigeria even at the turn of the 21 st century, Nigeria's corporate policy on shipping especially as it affects her indigenous operations remains hazy and at best epileptic. This research work in addition unraveled some of the policy and action that have kept Nigerian Indigenous Shipping Companies in a perpetual state of near paralysis and how such avoidable trends could be reversed in favour of growth and development of the Nation in general.
\end{abstract}

DOI: $10.7176 /$ JRDM/77-04

Publication date:July $31^{\text {st }} 2021$

\section{Introduction}

In discussing any economic issues in Nigeria since the existence of the nation, reference must be given to the Maritime and Oil sector in which Nigeria have more advantage to correct the balance of payment. Nigeria being a maritime nation and a member of Organization of the Petroleum Exporting Countries (OPEC) since 1971, the importance of shipping trade and petroleum to our national economic requires no lengthy explanation. Suffice it to say that the petroleum which accounts for more than ninety percent of Nigeria's foreign exchange earnings, also the Nigeria's economic configuration in the Maritime industry has consistently maintained a second place only to Crude Oil export as the Nation's highest revenue earners. Just as in any maritime nation, the industry is the gateway to the Nigerian economy as well as the barometer for measuring the inherent strength and weakness of the nations economy, in term of the volume of annual import and export. In the same vein it is also expected that indigenous shipping operators would through the adequate support and protection of government, develop the necessary capacity to compete in the international maritime environment. Nigeria a maritime nation and an OPEC member producing an average of 2,000,000 barrel per day, makes Nigeria by far the Cargo Oil and Gas producer within the Sub-Saharan West Africa Region, controlling over six per cent $(6 \%)$ of the world entire Crude Oil production. Dy this fact, it is unfortunate that available statistic shows that non of the crude oil Cargo are lifted by indigenous carriers, even as the importation of refined petroleum products rose from around 65 per cent to 95 per cent, the indigenous shipping operators are less than 5 per cent in contract of affreightment. If many developing countries have been inspired to own and operate national fleets, and the oil producing countries on the ground that large volume of their national products are carried by sea, Nigeria should join such countries. Despite lifting their own sea borne traffic, national fleet, contributes favourably to balance of payment accounts, maintains some national security, promotes national prestige, and improve employment. In most cases, emphasis has been more on the development of liner services than on operating tramps. Nigeria with a substantial foreign trade base, in ocean shipping is the major transport mode by which Nigeria transacts her international trade. Nigeria therefore, has duty to improve on her shipping services as a vehicle for the international trade as well as a means of earning and considering invisible incomes and improving her balance of payment, Nigeria shipping trade development should remains the focal point of the West African traffic. Olubanjo (1985) stated that, seventy percent of Cargo traffic to West African Countries from United Kingdom are for Nigeria, without Nigeria as a major market, international shipping and trade activities in West Africa would be much affected.

The Nigeria Shipping Policy as exposed in Decree 10 of 1987 has also largely been criticized as 
lacking the necessary ingredients capable of boosting the participation of Nigerian indigenous shipping practitioners. More so, the Nigerian National Petroleum Corporation (NNPC) Act No. 33 of 1977 (Federal Ministry of Justice, 1990) requires the corporation among other duties to provide and operates tanker-ships for the carriage of crude oil, products and derivatives. It is believed that those leaders who mooted the idea of establishing the NNPC did see the need for a achieving self-reliance in the affreightment of our petroleum by making the carriage of crude oil, its products and derivatives one of the duties of the NNPC.

Given the attested lucrativeness of the shipping trade and Nigeria's near exclusion from it benefits, this research work seeks to proffer some workable solutions to the avoidable problems of irrelevance faced by Nigeria in International shipping

The importance of maritime trade and petroleum to our national economy requires no lengthy explanation; despite a long history of crude oil production, exportation and at present the importation of refined products; no indigenous vessel (tanker) has lifted our crude oil which accounts for over ninety (90) percent of our foreign exchange (CBN 1994). Hence, the main objectives of this research work which is:

1. To appraise the present arrangement under which Nigeria's petroleum is being transported taking into consideration the country's economic and strategic interest.

2. To examine the problems hindering the effective participation of indigenous shipping operation in the lifting of crude oil.

3. To place the Nigerian indigenous shipping companies in a position to enhance their participation in the affreightment of Cargo particularly in Wet (Oil) Cargo lifting.

4. To establish by research, a procedure where government support through sound policy and other means to renew effectiveness and purposeful participation by the latter in the affreightment of Cargo.

5. To highlight the perceived handicaps of Nigeria's indigenous carrier and show how much can be ameliorated for positive result.

\section{Research Methodology}

\section{Selection of data}

In carrying out a research work of this nature, it is often difficult to study all samples in a population. Consequently, a concise research studying all samples in the population would provide precise and relevant answer to the problem being studied. In this work therefore, the researcher chose a sample of the population to be analysed and studied as a basis for generalization and conclusions. The researcher's choice in this work in the shipping institutions dominated at the Apapa area of Lagos which is the cockpit of maritime activities in Nigeria.

\section{Research Design}

This research work is of field nature. In carrying out this extensive work questionnaires, personal interviews where used in gathering primary data to enable the test of the veracity of the hypothesis formulated earlier on. Moreover, the secondary data which consists of existing data which predated the need for this research were equally used. These were obtained from textbooks, Journals, Periodicals and various libraries and personal collection of Texts. Personal interview were mostly used when required information could not be obtained through questionnaires or where the question were technical in nature that only the staff under whose jurisdiction the question was asked could answer. The researcher's targeted respondents from the structure of the questionnaire were the top and the middle level management staff in the shipping sector. It should be noted that even though top level management were in a better position to answer most of the questions, middle level manager, acting as representative of top management were chosen because of their accessibility. It was also evident that the relevant information needed would be easier source from them. A total of thirty-five questionnaire were distributed.

\section{Nature of Data Analysis}

Data analysis can either be based on percentage (\%) of responses (with total responses being taken as $100 \%$ ) or on the number of questionnaires actually returned. Responses to the questions were all analysed using percentage analysis. Also responses to question relating to the hypothesis formulated were further analysed using the chi-square $(\mathrm{X})$ technique.

\section{Research Hypothesis}

i. Nigeria does not generate enough Cargo and as such should not aspire to participate meaningfully in the shipping trade.

ii.Nigeria indigenous shipping companies do not need government support to operate effectively and competitively. 
iii.Nigeria shipping trade should be left in hands of the foreign operators since the latter have already been doing a good job.

Data presentation and testing of hypothesis

A total of 31 (thirty one) questionnaire were administered to operators in the shipping industry and NMA which constitute the focal point of this research work. Out of the $3 \mathrm{I}$, a total of thirty (30) were duly completed and returned. These should be adequately analysed in this chapter while the validity or otherwise of the hypothesis will also be put to test.

TABLE 1a. Showing distribution of managers and directors.

\begin{tabular}{|l|l|l|l|}
\hline Designation & $\begin{array}{l}\text { Number } \\
\text { Administered }\end{array}$ & $\begin{array}{l}\text { Percentage } \\
\text { Administered }\end{array}$ & $\begin{array}{l}\text { Number } \\
\text { Returned }\end{array}$ \\
\hline MANAGING DIRECTORS & 10 & 32.26 & 9 \\
\hline ASST. DIRECTORS(NMA) & 3 & 9.68 & 3 \\
\hline SHIPPING MANAGERS & 3 & 9.68 & 3 \\
\hline COMMERCIAL MANAGERS & 15 & 48.38 & 15 \\
\hline TOTAL & 31 & 100 & 30 \\
\hline
\end{tabular}

From the above table it can be seen that the percentage returned is $30 \backslash 31 \times 100=96.77 \%$. In this case, our statistical decision about the population would be made on the basis of this sample information. It is also the researcher's view that the numbers of questionnaires returned (30 or $96.77 \%$ ) is more than adequate to give objectively to our analysis.

\section{Analysis and interpretation of data}

Table 1b. Showing the positions (official designations) in this organization (Authority)

\begin{tabular}{|l|l|l|}
\hline Option & Number of Responses & Percentage \% \\
\hline Managing Directors & 9 & 30 \\
\hline Asst. Directors (NMA) & 3 & 10 \\
\hline Shipping Managers & 3 & 10 \\
\hline Commercial Managers & 15 & 50 \\
\hline TOTAL & 30 & $100 \%$ \\
\hline
\end{tabular}

From the Table 1 above, it can be seen that Nine (9) respondents or 30\% of the respondents are Managing Directors of (Shipping Companies). Three (3) respondents or 10\% are Asst. Directors (NMA), three (3) respondents or $10 \%$ are Shipping Managers, while fifteen (15) respondents or $50 \%$ of the respondents are Commercial Managers of indigenous shipping companies.

Table 2. Showing the number of years that operators have operated in the shipping industry.

\begin{tabular}{|l|l|l|l|}
\hline $\begin{array}{l}\text { Option } \\
1-5 \text { years }\end{array}$ & Responses & $\begin{array}{l}\text { Percentage } \% \\
6.66\end{array}$ \\
\hline $6-10$ years & & 5 & 16.67 \\
\hline $11-15$ years & & 8 & 26.67 \\
\hline 16 and above & & 15 & 50 \\
\hline TOTAL & & $-100 \%$ \\
\hline
\end{tabular}

From the table above, it can be observed that percentage of staff who has been operating in shipping companies and industries for over Ten (10) year is the sum of $26.67 \%$ and $50 \%$ which resulted into $76.67 \%$ suggesting that the offices can understand the research objectives.

Question three: Are you familiar with the vital provisions of the Nigerian Shipping Policy (Decree 1 O of 1987)?

Table 3

\begin{tabular}{|l|l|l|}
\hline Option & Responses & Percentage \% \\
\hline YES & 28 & 93.33 \\
\hline NO & 2 & 6.67 \\
\hline TOTAL & 30 & $100 \%$ \\
\hline
\end{tabular}

From Table 3, it was observed that 28 of the respondents (or 93.33\%) are quite familiar with the vital provisions of the Nigerian Shipping Policy. 
Question four: Are Nigerian indigenous operators well placed to participate in the lifting of the nation's crude oil?

Table 4

\begin{tabular}{|l|l|l|}
\hline Option & Responses & Percentage \% \\
YES & 23 & 76.67 \\
\hline NO & 7 & 23.33 \\
\hline TOTAL & 30 & $100 \%$ \\
\hline
\end{tabular}

Table 4, reveals that 23 respondents constituting $76.67 \%$ are of the opinion that indigenous operators are not well placed to lift the nation's crude oil.

Question five: Do you think a well defined Cabotage Law would positively affect the effective participation of indigenous operators in Cargo affreightment?

Table 5

\begin{tabular}{|l|l|l|}
\hline Option & Responses & Percentage \\
YES & 30 & 100 \\
\hline NO & 0 & 0 \\
\hline TOTAL & 30 & $100 \%$ \\
\hline
\end{tabular}

In Table 5 above, it was noticed that totality of the respondents (100\%) are of the view that a well defined Cabotage Law would positively impact the effective participation of the indigenous operators in Cargo affreightment.

Question six: Should the Ship Acquisition and Ship Building Fund (SASBF) be restored.

Table 6

\begin{tabular}{|l|l|l|l|}
\hline Option & Responses & & Percentage \\
\hline YES & & 30 & 100 \\
\hline NO & & 0 & 0 \\
\hline TOTAL & & 30 & $100 \%$ \\
\hline
\end{tabular}

All respondents to question six agree that the Ship Acquisition and ship Building Fund (SASBF) should be restored i.e. $100 \%$ (Table 6).

Question seven: Are you in favour of the current trade terms of FOB (export) and CIF (import) being practiced in Nigeria?

Table 7

\begin{tabular}{|l|l|l|}
\hline Option & Responses & Percentage \\
\hline YES & I & 3.33 \\
\hline NO & 29 & 96.67 \\
\hline TOTAL & 30 & $100 \%$ \\
\hline
\end{tabular}

The respondents of $96.67 \%$ are against the trade terms of FOB (Export) and CIF (Import) being practiced in Nigeria while 1 (one) of the respondent (or 3. 33\%) is in support of trade terms.

\section{Hypothesis testing}

In this Section the three (3) hypothesis formulated was placed under empirical test.

The chi-square technique will be judiciously used to determine the veracity or otherwise of the formulated hypothesis. A cursory look at the questionnaires reveals that question 10, 11 and 15 are the one most closely related to the hypothesis.

\section{Hypothesis One}

Ho: Nigeria Indigenous Shipping Companies do not need government support to be effective and competitive $\mathrm{H}$ : Nigeria Indigenous Shipping Companies need Government support to be effective and competitive. Question Ten: Do you think the Government support would positively impact the effective participation of indigenous operations in Cargo affreightment? 
Table 8

\begin{tabular}{|l|l|l|}
\hline Option & Responses & Percentage \\
Yes & $28(15)$ & 93.33 \\
\hline No & $2(15)$ & 6.67 \\
\hline TOTAL & 30 & $100 \%$ \\
\hline
\end{tabular}

Table 8 shows that while $6.67 \%$ of the respondents see that the Government support will not likely have a positive effect on indigenous participation in Cargo affreightment $93.33 \%$ see otherwise. The analysis reveal therefore that the formulation of Government policy such as Carbotage Law would go a long way in enhancing the participation of Indigenous Shipping Companies in Cargo affreightment.

The bracket number in table eight represent the expected frequencies. The expected frequency $(\mathrm{E})=\mathrm{EX} / \mathrm{n}$ $=30 / 2=15$

The information presented in Table eight can be re-arranged to show observed frequency (0), expected frequency (E) deviation (0-E), deviation square (0-E), deviation square and weighted (0-E)IE as shown in Table 9 below:

Table 9

\begin{tabular}{|l|l|l|l|l|l|}
\hline Option & 0 & E & $0-\mathrm{E}$ & $(\mathrm{O}-\mathrm{E})$ & $(\mathrm{O}-\mathrm{E}) 2 / \mathrm{E}$ \\
\hline Yes & 28 & 15 & 13 & 169 & 11.27 \\
\hline No & 2 & 15 & 13 & 169 & 11.27 \\
\hline TOTAL & 30 & & 0 & & 22.54 \\
\hline
\end{tabular}

From table $9, \mathrm{X}^{\prime} \mathrm{Cal}=22.54$. To determine the table chi-square $\left(\mathrm{X}^{2}\right.$ table $)$

Degree of freedom $(\mathrm{m})=\mathrm{n}$

$2-1=1$

So assuming a 0.5 level of significant $\left(95 \%\right.$ confidence level) $\mathrm{X}^{2} 0.05$ at 1 degree of freedom $=3.841$ ie $\mathrm{X}^{2}$ $(0.05,1)=3.8481$

Accept $\mathrm{H}$ if $\mathrm{X} \mathrm{Cal}<\mathrm{X}^{2}$ table

Reject HA if $\mathrm{Xx} \mathrm{Cal}>\mathrm{X}^{2}$ table

Since Cal $x>X^{2}$ table $(22.54>3.841)$

The null hypothesis is rejected but to accept the alternative hypothesis which state that Nigeria Indigenous shipping companies need Government support to be effective in, operation and competitiveness.

Hypothesis Two

Ho. Nigeria does not generate enough Cargo and as such should not aspire to participate meaningfully in the shipping trade.

H. Nigeria generates enough Cargo and as such should aspire to participate meaningfully in the shipping trade

Question Eleven: Does Nigeria generate enough Cargo to warrant her effective participation in the shipping trade?

Table 10

\begin{tabular}{|l|l|l|}
\hline Option & Resources & Percentage \\
\hline Yes & $26(15)$ & 86.67 \\
\hline No & $4(15)$ & 13.33 \\
\hline TOTAL & 30 & $100 \%$ \\
\hline
\end{tabular}

The $86.67 \%$ of the respondent agree that Nigeria generates enough Cargo to warrant Indigenous participation in the shipping trade while the other 13. 33\% think otherwise (Table 10) going by this response, it goes without saying that Nigeria definitely needs to develop her shipping trade as she generates enough Cargo to warrant a strong market entry point.

The bracketed numbers in table 10 represent the expected frequencies:

The expected frequency $(\mathrm{F})=\mathrm{EX} / \mathrm{n}$

$=30 / 2=15$

The information in Table 10 can be arranged to show observed frequency (0) expected frequency (E) deviation $(0-E)$ and deviation square $(0-E)^{2}$ as shown in Table Eleven below:

Table 11

\begin{tabular}{|l|l|l|l|l|l|}
\hline Option & 0 & E & O-E & $(0-E) 2$ & $(\mathrm{O}-\mathrm{E}) 2 / \mathrm{E}$ \\
\hline Yes & 26 & 15 & 11 & 121 & 8.07 \\
\hline No & 4 & 15 & -11 & 121 & 8.07 \\
\hline TOTAL & 30 & & 0 & & 16.14 \\
\hline
\end{tabular}

From Table $11, \mathrm{X}^{2}$ computed $=16.14$ to determine the table chi-square $\left(\mathrm{X}^{2}\right.$ table) Degree of freedom $(\mathrm{m})=\mathrm{n}$ $-1$ 
$2-1=1$

Assuming a 0.5 level of significant $\left(95 \%\right.$ confidence level) $\mathrm{X}^{2} 0.05$ at 1 , degree of freedom $=3.481$ ie $\mathrm{X}^{2}$ $(0.05,1)=3.841$

Since computed $\mathrm{X}^{2}>\mathrm{X}^{2}$ table that is $(16.14>3.841)$.

The null hypothesis which states that Nigeria does not generate enough Cargo and as such should not aspire to participate meaningfully in the shipping trade is rejected.

Hypothesis Three

Ho: Nigeria Shipping trade should be left in the hand of the foreign operators.

H. Nigerian shipping trade should not be left in the hands of the foreign operators

Question Fifteen: Should Nigeria shipping trade be left in the hands of foreign lines.

Table 12

\begin{tabular}{|l|l|l|}
\hline Option & Responses & Percentage \\
Yes & $7(15)$ & 23.33 \\
\hline No & $23(15)$ & 76.67 \\
\hline TOTAL & 30 & $100 \%$ \\
\hline
\end{tabular}

Table 12 above, shows that $23.33 \%$ of the respondents believed that Nigerian shipping trade should be left in the hands of foreign operators while the majority of

$76.67 \%$ do not agree with the position of the foreign operators.

Judging from the pattern of response obtained it appear that majority of shipping operators in Nigeria are of the opinion that Nigeria shipping trade should involve indigerious participation. The bracketed numbers in table 12 represent the expected frequencies.

The expected frequency $(\mathrm{E})=\mathrm{EX} / \mathrm{n}$

$=30 / 2=15$

The information as shown in table 12 can be re-arranged to show observed frequency $(0)$ expected frequency $(\mathrm{E})$, deviation $(0-E)$, deviation square $(0-E)^{2}$ and deviation squared and weighted $(0-E)^{\prime} / E$ as shown below in table 13 .

Table 13

\begin{tabular}{|l|l|l|l|l|l|l|c|}
\hline Option & 0 & 0 & $\boldsymbol{E}$ & $\mathbf{0 - E}$ & $\mathrm{O}-\mathrm{E}$ & $(0-\mathrm{E}) 2$ & $(\mathrm{O}-\mathrm{E}) 2 / \mathrm{E}$ \\
\hline Yes & 7 & 26 & 15 & -8 & 11 & 64 & 4.27 \\
\hline No & 23 & 4 & 15 & 8 & -11 & 64 & 4.27 \\
\hline TOTAL & $\mathbf{3 0}$ & 30 & & 0 & 0 & & $\mathbf{8 . 5 4}$ \\
\hline
\end{tabular}

In the table $13, \mathrm{X}^{2}$ computed $=8.54$. To determine the table chi-square $\left(\mathrm{X}^{2}\right.$ table $)$ Degree of freedom $(\mathrm{m})=\mathrm{n}--1$ $2-1=1$

Assuming a 0.5 level of significance $(95 \%)$ confidence level $\mathrm{X}^{2} 0.05$ at 1 degree of freedom $=3.41$ ie $\left(\mathrm{X}^{2}\right.$ $(0.05,1)=3.841$

Since computed $X>X$ table $(8.54>3$. 841) the alternative hypothesis which states that Nigerian shipping trade should not be left in the hands of foreign operators is accepted

\section{Method of selecting crude oil customers}

The qualifications required to buy Nigeria crude oil are as follows:

1. Potential customers are required to be end-users, or those who have outlets for refined products.

2. They are expected to submit credit references from their banks and provide their company's three years' audited accounts and annual reports. On the submission of these documents, the NNPC uses foreign intelligence companies like Dun and Bradstreet to provide confidential report on the applicants. The information gathered from these sources are used to prepare a list of suitable companies for contract award.

3. Successful applicants must demonstrate commitment to the development of the economy by planning or making investment here. Contract duration is usually one year renewable, government may decide to award longer term contracts.

4. In choice of crude oil customers, the need to protect the federation account is paramount. The NNPC's view is that the customers to whom crude oil is allocated should be well established companies with a minimum average turnover of over US \$ 100 million (above N8 billion) during the preceding three years, a network of over US \$ 40 millton (about N32 billion) and must be capable of posting a US \$ 1 mill ion about (N80 Million) performance bond through a reputable banks. The bond will be cashed and forefeited to the NNPC if after six months of a crude oil contract signature, the customer is not poised to invest in the upstream sector of the Nigeria oil industry or in any other vital sector of the Nigerian economy.

Ideally, as said earlier, the customer should be an end-user i.e. a refiner. A major crude oil trader meeting the assets base criterion refers to above could also be an acceptable customer.

Crude oil terminal and locations 
There are eight oil terminals in Nigeria from where ten different grades or types of crude oil and condensate are exported. The oil terminals, the operations and the various crude oil grades are as stated below.

\begin{tabular}{|l|l|l|l|}
\hline Terminal & Crude oil grade & Location & Terminal operators \\
\hline Bonny & $\begin{array}{l}\text { Bonny medium \& } \\
\text { Bonny light }\end{array}$ & Eastern zone & S.P.D.C \\
\hline Odudu & Odudu blend & Eastern zone & Elf petroleum Co. limited \\
\hline Forcados & Dorcados blend & Western zone & S.P.D.C \\
\hline Escravos & Escravos light & Western zone & Chevron Nig. Ltd. \\
\hline Oloibiri & Pennington light & Eastern zone & Topcon Unlimited \\
\hline Antan & Antan blend & Eastern zone & Ashland Oil Co. Ltd. \\
\hline Brass & $\begin{array}{l}\text { Qua IBOE light \& Osond } \\
\text { condensate } \\
\&\end{array}$ & Eastern zone & Nigerian Agip Oil Co. Ltd. \\
\hline Qua lboe & Exxon - Mobil producing \\
\hline
\end{tabular}

Source; NNPC/NAPIMS Regional Distribution of crude oil statistics.

These terminals are in two categories on shore and offshore. The onshore terminals arc Bonny, Brass, Forcados, Escravos and Antan, while the offshore terminals are Odudu and Oloibiri.

Arguements against indigenous participant.

NNPC's argument that it has no sufficient capital to own a tank.er fleet for the carriage of its crude oil is rather an after-thought. In our present economic situation, this argument sounds credible, but what could have, been the cause of this strategic neglect during the oil boom days of the 1970s to the early 1980s? What was done in respect of the country's Liquefied National Gas (LNG) project for which some gas

arriers have already been purchased should have also been done in respect of our crude oil. NNPC does not have to own VLCCs in order to be involved in the carriage of its crude oil. For a start, even one -medium size tanker supplemented with time chartered vessels could serve our strategic interest. As at September 1995, new and

14 years old second hand prices of 80,000 DWT Tanker were about US\$ 43 million (NJ. 4 billion) and US \$ 14.5 million (N 1.2 billion) respectively (Lloyd's Vol 17, no. 9 September 1995), cannot NNPC afford such amount?

NNPC argues that it is unprofitable because of lack of competitiveness for the NNPC to be involved in the transportation of its crude oil is not plausible. If it is not profitable, some oil companies which own and/or charter tankers to carry their own petroleum will not be doing so. More over things like strategy interest should not be tied to th profitability of a venture. Otherwise there will be no justification for all the naval ships we have.

As regards the idea that crude oil market is a buyer's market, does it only apply to Nigeria? If not, what then do the oil exporting countries that own tanker fleets do with their vessels? If exporters of low grade crude oil such as Saudi Arabia could get customers who are willing to buy on C \& F terms, NNPC could also get some consumers that will buy the high grade Bonny light on $\mathrm{C} \& \mathrm{~F}$ basis.

Talking about lack of technical expertise on the part of Nigerian Shipping Companies as a reason for their non -- involvement in the carriage of Nigeria Crude Oil, cannot be a serious excuse. There are quite a good number of well qualified and capable Nigerian marine personnel who have experience in tank.er operations. There are up to 325 master mariner 5 of whom are Captains of tankers (NAMM). Some of these people are effectively handling foreign tankers.

Another reason often given for non-indigenous participation in the carriage of petroleum is that Nigerian shipping companies do not have the resources to off-set liabilities associated with crude oil shipment. Typical example of such liabilities are payments in respect of oil pollution and non-delivery of Cargoes resulting from the faults of carriers. This appears to be a plausible excuse especially as crude oil pollution liabilities could run into hundreds of millions of dollars. These are however insurable risks which can always be taken care of by 'taking proper insurance policies. In addition, these risks could be put under the responsibility of shipowners if chartered tonnage is employed. 
Pertaining to the issue of credibility and security there has not yet been a reported case of a Nigerian Shipping Company that was given the opportunity to carry, but failed to perform or deliver the Cargo.

From the foregoing, the reasons given for the non-participation of Nigeria in the carriage of petroleum are not concrete enough. In addition there are some compelling reasons as been seen in this study why indigenous participation is necessary.

Tanker tonnages of some OPEC countries

For a realistic assessment of the situation, there is a need to take a look at what obtains in some other countries, which like Nigeria have interest in the carriage of crude oil and its products.

Towards this end, a few countries namely, Iran, Iraq, Kuwait, Libya, Mexico, Saudi Arabia and Venezuela are some of the nations that should have interest in the carriage of petroleum. This is because their economics also depend heavily on foreign exchange earnings from petroleum as shown in the table below (UNCTAD 1993).

Owning of tanker fleets by these countries implies that they attach importance to the carriage of crude oil and its products which must be because of economic and/or strategic reasons as no nation will invest in a venture which has no direct or indirect relevance to her national interest.

TANKER TONNAGE AND PERCENTAGE DEPENDENCE ON PETROLEUM OF SOME OIL PRODUCING STATES

\begin{tabular}{|l|l|l|l|l|l|}
\hline S/No & Country & Noof tankers & Total GRT & Total DWT & $\begin{array}{l}\text { Dependence } \\
\text { On Petroleum }(\%)\end{array}$ \\
\hline 1. & IRAN & 45 & $2,346,894$ & $4,708,533$ & 96 \\
\hline 2. & IRAQ & 27 & 769,808 & $1,427,526$ & 674 \\
\hline 3. & KUWAIT & 26 & $1,261,209$ & $2,150,947$ & 64.5 \\
\hline & LIBYA & 15 & 708,030 & $1,343,254$ & 93.4 \\
\hline & MEXICO & 36 & 586,524 & 994,897 & 37.3 \\
\hline & SAUDI ARABIA & 88 & $1,636,265$ & $3,113,598$ & 78.4 \\
\hline & VENEZUELA & & 470,310 & 761,508 & 85.6 \\
\hline
\end{tabular}

In correlating, the Libya's low ownership of tanker to her $93.4 \%$, is dependent on Suadi Arabia and Iran having large numbers of tankers 88 and 45 respectively.

\section{The needs for indigenous participation}

1. Saving of foreign exchange:

2. Development of support industries

3. Creation of employment opportunities:

4. Acquisition of expertise

5. Strategic interest

In addition, the role played by Iraqi tanker fleet in sustaining the country's oil export during the 1991 Gulf War needs not be overemphasized as foreign tankers at certain

stage were unwilling to lift Iraqi oil due to war risks, Nigeria may be free from war I

situations today but what of tomorrow? Under such a circumstance which can never be ruled out in the increasingly volatile world political environment, will it still be uneconomic to owned a tanker fleet? Certainly not. Also, there is no guarantee that the present buyer who purchased oil on FOB will always be there to patronize people who prefer to buy on $\mathrm{C} \& \mathrm{~F}$ may become customers in the future and will be better of under such a situation if Nigeria own tank.er tonnage.

\section{RESEARCH FINDING, CONCLUSION AND RECOMMENDATION. SUMMARY OF FINDINGS}

Going by the analysis carried out, it can be unambiguously stated that there is an over whelming need for indigenous shipping companies in Nigeria to be fully supported and encouraged by the Government in order to increase their participation in international shipping trade.

The following therefore, constitute a summary of findings based on the empirical analysis of data:

1. The result obtained from the test hypothesis I (one) shows that Nigeria does generate enough Cargo to necessitate effective participation by her indigenous shipping companies in the shipping trade.

2. The test carried out hypothesis 2 (two) showed that Nigerian indigenous shipping companies actually need Government support such as Cabotage Law to make them effective and competitive.

3. The result obtained from our test of hypothesis 3 (three) reveals that Nigerian Shipping Trade should not be left in the hands of foreign operators to the detriment of the indigenous shipping companies.

4. From the study, it has also been discovered that for the Federal Government to actualize her dreams of 
indigenous fleet expansion, the Ship Acquisition Fund must be restored and restructured.

5. It was also found out that the prevailing trade term of FOB (export) and CIF (import) being practiced by the NNPC in highly detrimental to the aspiration of indigenous and the nation economy in general.

6. It was observed that the National Maritime Authority needs to be repositioned to adequately meet the needs of shipping development in Nigeria.

7. Finally, it was also obvious that it would be unwise for Nigeria to jettison the policy of Cargo allocation but to fully embrace trade liberalization.

\section{Conclusion}

In the world of today, the only decimal that has remained constant, is change. Change at a very rapid pace, be it in the field of science, technology, information management, medicine, shipping etc concepts such as globalization and trade liberalization have of late impacted very heavily on the international shipping trade. Yet Nigeria appears to have remained static and retrogressive as far as the development of her shipping trade is concerned.

It is worth remembering that over $90 \%$ movement bulk Cargo world-wide including Nigeria is via shipping. This indicates that international shipping trade remains a cardinal factor in global business transactions and interactions. Since the demise of the Nigeria Na-tional Shipping Line (NNSL) and the suspension of the SASBF in 1996, no visible action has been taken by the Federal Government to engage in the development of the Nation's shipping industry and the expansion of the indigenous fleet. This lukewarm approach has not only ensured a stunted growth for the nation's indigenous fleet, it has also made it impossible, this far for Nigeria's shipping companies to enter into the lucrative trade of lifting the nation's crude oil. The result has been an annual loss of over US $\$ 500,000$ (N40 million) in freight value to the foreign shipping lines which for over to 40 years, have dominate this trade.

Without any doubt, Nigeria possesses all the inherent qualities necessary to develop herself into the league of Great Maritime Nation's of the World. With an Economic Exclusive Zone (EEZ) straddling volumes of exportable crude oil and gas, the nation has indeed, no excuse not to establish her potentials in the shipping trade.

\section{Recommendation}

As has been seen so far, there exists a yearning for the development of Nigeria's Shipping Industry and the expansion of the fleet of indigenous operators in the sector. It is against this backdrop that this researcher has in this work proffered the following set of practical recommendations.

The Federal Government should without hesitation, implement the well defined and positioned Cabotage Law that would serve to protect indigenous shipping companies and ease their entry into the crude oil and petroleum products affrcightment trade. It is saddening to note that up till this moment, foreign companies are still dominating the movement of this lucrative Cargo around Nigeria waters and across the West Coast of Africa. The Government should borrow a leaf from the United States of America who though is the loudest advocate of trade liberalization and globalization firmly protects her indigenous shipping trade through the means of a cabotage law as embodied in the Jones Act of 1920.

For Nigeria's Shipping Industry to be intact the National Policy must be thoroughly re-examined by a team of maritime and legal experts so that all perceived unworkable provisions are either modified or expunged. This is necessary because much of the cardinal provisions of the Shipping Policy such as the Ship Acquisition and Ship building Fund and the Cargo allocation system which were meant to boost Nigeria's position in shipping, have mainly been implemented in the breach.

As a corollary to number two above, the Federal Government should restore with modification, the SASBF and Cargo allocation policy. It must be stated here however, that rather than allow the provisions implementation methods to prevail, the NMA must be made to work alongside time tested financial institutions and experts towards the disbursement of the Ship Acquisition Loan. Proper modalities for repayment should be drawn up to avoid the present debasing spectacle where NMA has to drag defaulters to Civil Courts.

From the analysis of the questionnaire in the previous chapter, the fact remains that the Federal Government must of necessity re-empower the NMA to implement the provision of the National Shipping Policy Decree 10 of 1987 in matter relating to the trade of terms of FOB and C \& F. The Government should ensure that all export from Nigeria especially crude oil and its by-products including gas must be done on Cost Insurance and Freight (CIF) while all imports should be Free On Board (FOB). That way, indigenous fleet expansion and shipping development would not only be realized, the nation's economy itself would receive a boost by

way of huge freight earnings. In the aspect of Indigenous Shipping Operators, they should stand up NNPC wrong on their arguments and fear against them the affreightment.

It is recommended that the coming together of some indigenous shipping companies to form consortia such as the Joint Service Consortium, so their handicap in terms of resources will be reduce.

Lastly and perhaps most importantly it is recommended that the Federal Government should apart from encouraging private sector initiative in shipping development, to demonstrate the political will and commitment 
to create and enforce such legislation that would make it difficult if not impossible for the foreign shipping operators to continue to dominate the Nation's shipping trade.

\section{Bibliography}

ACTIVE TITLE "Keeping One Step A head" in Lloyd's Shipping Economist February 1995 p6

BADEJO, DELE (1998) "Maritime Transportation in Nigeria" 1" Edition, Rex Charles Publications, Ibadan, Nigeria.

BELL, P and CLOKE, P (Ed) (1990) Deregulation and Transport; London.

EKONG, B.,U. (1986) "Shipping and its effects on the Nigeria Economy; Improving Shipping and Port Performance in Nigeria". Ola Bangbose Piss \& Co. Lagos.

FILEEN KANE (1987) "Doing your own Research".London, Marion Byer, 1987 p. 150

FULLERTON, B (1990) "Deregulation in a European contec" London.

GENERAL ABIOLA, O. FALASE-Aluko "New development in the Admiralty Jurisdiction of the Federal High Court (1995) J. A. L. Vol 39 No. 2"

GUIDE TO WORLDWIDE MARITIME TRAINING (Lloyd's Ship Management Directory)

HENRY, MUSH (1974) Statistic: The Fundamentals for Research New York, John Wiley and son Inc 1974. pp $17-183$

HERBERT, B Jnr.(1972) Social Statistics Revised 2nd Edition Washington, Mcrgraw Hill Book Co. 167

HOYLE B. S. and KNOWLES (1992) Modern Transport Geography Bellhaver press London, New York

LONE, C. KENDALL (1986) The Business of Shipping Fifth Edition London Chapman and Hill publisher pp 1821.

MURRAY SPIEGEL Theory and Problem of Statistic SI (Metric) Edition, New York, Schaum Outline See(es Migraw Hill Book Co. 1973, p. 191

NKEM, JACOBS (1995) In "Developing Nigerian Oil Industry "The Vanguard January 12, p 16.

SEA WAYS (1996) The International Journal of the Nautical Institute. 